\title{
Radosław Kłus
}

Wroclaw University of Economics and Business, Poland e-mail: radoslaw.klus@ue.wroc.pl

ORCID: 0000-0002-6776-9178

\section{Iwona Chomiak-Orsa}

Wroclaw University of Economics and Business, Poland e-mail: iwona.chomiak@ue.wroc.pl

ORCID: 0000-0003-3550-8624

\section{THE IDENTIFICATION OF KEY STAKEHOLDERS AND INFORMATION RESOURCES IN THE INFORMATION PROCESSES OF A NON-PROFIT ORGANIZATION USING THE EXAMPLE OF THE STUDENTS' GOVERNMENT OF WROCLAW UNIVERSITY OF ECONOMICS AND BUSINESS}

IDENTYFIKACJA KLUCZOWYCH INTERESARIUSZY ORAZ ZBIORÓW INFORMACYJNYCH W PROCESACH INFORMACYJNYCH ORGANIZACJI NON PROFIT NA PRZYKLADZIE SAMORZĄDU STUDENTÓW UNIWERSYTETU EKONOMICZNEGO WE WROCLAWIU

DOI: $10.15611 /$ ie.2021.1.04

JEL Classification: D83, K10, K20, M15, M19

(C) 2020 Radosław Kłus, Iwona Chomiak-Orsa

This work is licensed under the Creative Commons Attribution-ShareAlike 4.0 International License. To view a copy of this license, visit http://creativecommons.org/licenses/by-sa/4.0/

Quote as: Kłus, R., and Chomiak-Orsa, I. (2021). The identification of key stakeholders and information resources in the information processes of a non-profit organization using the example of the Students' Government of Wroclaw University of Economics and Business. Business Informatics. Informatyka Ekonomiczna, (1).

Streszczenie: Identyfikacja i poprawna organizacja procesów informacyjnych stanowią dla wielu organizacji kluczowy czynnik sukcesu. Temu zagadnieniu poświęca się wiele miejsca 
w odniesieniu do przedsiębiorstw, jest ono jednak marginalnie traktowane w odniesieniu do działalności organizacji non profit. Wnioski z badań literaturowych zdeterminowały cel artykułu, który stanowią identyfikacja interesariuszy procesów oraz charakterystyka zasobów informacyjnych niezbędnych dla tych interesariuszy. W artykule przeprowadzono analizę oddziaływania informacyjnego procesów i potrzeb informacyjnych interesariuszy procesów w organizacji non profit na przykładzie działalności organizacji studenckiej, jaką jest Samorząd Studentów Uniwersytetu Ekonomicznego we Wrocławiu. Jako narzędzia badawcze zastosowano pogłębioną analizę literatury, analizę rozwiązań informacyjnych w obszarze organizacji non profit, obserwację współuczestniczącą i wieloletnie doświadczenie autora artykułu ze współpracy w ramach zarządzania z omawianą organizacją studencką.

Słowa kluczowe: procesy informacyjne, organizacja studencka, interesariusze, zasoby informacyjne, działalność non profit.

\begin{abstract}
Summary: The identification and correct organization of information processes is a key success factor for many organizations. A lot of space has been devoted to this issue in relation to businesses, while it is only treated marginally in relation to the activities of non-profit organizations. The above conclusions, resulting from the literature research, determined the purpose of the article, namely the identification of process stakeholders and the characterization of information resources necessary for these stakeholders. The article analyses the scope of the information impact of the processes and the information needs of stakeholders in a nonprofit organization using the example of the activities of a student organization, i.e. the Student Government at the University of Economics in Wrocław. The research tools included an in-depth analysis of the literature, analysis of information solutions in the field of nonprofit organizations, participant observation as well as many years of experience on the part of the authors, resulting from cooperation in the management of a student organization, i.e. the Student Government at the University of Economics in Wroclaw.
\end{abstract}

Keywords: information processes, student organization, stakeholders, information resources, non-profit activity.

\title{
1. Introduction
}

The effectiveness of an organization depends on the correct organization of the information system. The correctness of its functioning depends on the optimal structure, as well as the proper organization of information processes. Both layers, structure and process, determine the efficiency of the information system. Striving to optimize business processes is a natural development direction for all organizations, including non-profit ones. It is important that the analysis of processes and their improvement take place simultaneously in two perspectives: static - reflecting the structure of the process, and dynamic - illustrating the operating algorithms. The authors focused on the analysis of the structural layer of business processes implemented in non-profit organizations using the example of the activities of the Student Government at the University of Economics in Wrocław. In this context, the main groups of stakeholders, who are the subjects of the information processes, were identified and discussed. Against this background, information collections were 
characterized, which were created, collected and processed by the aforementioned stakeholder groups.

The aim of the article was to indicate and characterize the information needs of selected stakeholder groups participating in information processes carried out in non-profit organizations, using the example of the Student Self-Government at the University of Economics in Wrocław.

\section{Literature research}

The analysis of the literature carried out by the authors concerned mainly the definition of the concept of a non-profit organization, and the classification of the key characteristics of this concept.

A non-governmental organization may take different names and definitions, depending on the specificity of its activities (Grzelońska 2011; 325-344; GUS, 2019, p. 9; Handbook on non-profit institutions in the system of national accounts, 2003, pp. 18-20; Ustawa z dnia 24 kwietnia..., 2003). Regardless of the minimal differences in the form of functioning, the common denominator for all non-governmental organizations is their acting for the benefit of the public benefit without making a profit from this activity (Praska-Kruszyńska, 2003, p. 82; Szulc, 2010, p. 81-99; Zawadzki, 2007, p. 9). On the other hand, in sociology, the concept of a social organization is somewhat broader and defines it as an organized set of joint social activities and relationships that perform essential functions for the sake of the social good, creating a general whole that differs from other similar organizations (Dart, 2004, pp. 290-310; Mrzygłocka-Chojnacka, 2014, pp. 162-164; Shaw and Allen, 2009, pp. 83-96).

There are many definitions of social organizations, but the most common, due to the essence of their operation, are as follows:

- non-profit organizations, which means taking actions not directed at profit but only social results;

- non-profit-making, which do not operate due to the desire to make a profit, but may apply to various institutions for income, with the assumption that all the income generated will be allocated to the statutory objectives of the organization;

- non-governmental, acting for the benefit of the community, are independent of the government, state administration, but under certain exceptions, it can carry out tasks commissioned by the state apparatus;

- NGOs, also known as non-governmental organizations, freely translated (especially at international level), NGOs are defined as acting for the public benefit, and the name of the NGO itself is used primarily in international contacts;

- citizen, focused on acting for the benefit of society, for example locally, or more broadly; the concept of civic organization indicates the secondary role of the state and the greater self-organization of citizens (Gliński, 2006);

- public interest, i.e. organizations having as their primary purpose the support and service of the public; 
- the third sector, i.e. organizations operating in a separate area than in the public administration sector or the sector of economic organizations (Bode, 2006, pp. 346-359; Dart, 2004, pp. 290-310; Zawadzki, 2007, pp. 9-10).

Additional terms for social organizations are: private voluntary organizations; non-governmental organizations formed by government agencies; quasi-governmental organizations; non-governmental organizations formed by enterprises; non-governmental organizations established by the founder; political non-governmental organizations (Domański, 2010, p. 28); charities and caring organizations; non-profit organizations (Fudaliński, 2013, p. 21).

When analysing the legal basis for the functioning of social organizations, one should take into account the fact that the definition of their operation has not been fully clearly defined, therefore there is no one legal system of operation in the legal and economic sphere common to all types of social organizations. In Polish law, the most appropriate legal acts regulating the functioning of social organizations are:

- Act of 24 April 2003 (Ustawa z 24 kwietnia 2003 r. o działalności pożytku publicznego i o wolontariacie);

- Act of 7 April 1989 (Ustawa z 7 kwietnia 1989 r. prawo o stowarzyszeniach);

- Act of 6 April 1984 (Ustawa z 6 kwietnia 1984 r. o fundacjach);

- Act of 2 July 2004 (Ustawa z 2 lipca 2004 r. o swobodzie działalności gospodarczej);

- Act of 29 August 1997 (Ustawa z 29 sierpnia 1997 r. Ordynacja podatkowa).

Thus, it can be noted that apart from the traditional division of public benefit organizations into those indicated above, organizational units such as associations or foundations which implement statutory objectives based on the main principle of activity for the public benefit, are also used in practice. Regardless of the principles of the functioning of a social organization, those that operate legally formalized by the act, just like any business entity, are subject to the provisions of the tax law and the Accounting Act in the scope of liability given by the acts and the law regulating their functioning (Hwang and Powell, 2009, pp. 268-298; Kreutzer and Jäger, 2011, pp. 634-661).

\section{Methodology}

The considerations presented in the article are the result of the research process.

The first stage of the research was to conduct a critical analysis of the literature in the area of defining and characterizing non-profit organizations. Thus the authors reviewed domestic and foreign scientific studies, and as a result of the conducted systematic analysis of the literature, practical research questions were defined:

- Can the main characteristics of non-profit organizations be defined?

- Does the definition of a non-profit organization indicate the key information processes that it should implement? 
- Is a student government an example of a classic non-profit organization?

- Is it possible to define key information processes that should be implemented in SSUEW?

The above research questions determined the elements of the research methodology, which included the following research techniques:

- analysis of the founding documents and documents determining the functioning of the SSUEW,

- analysis of solutions for the organization of process management,

- participant observation,

- direct participation in information processes.

The discussed research procedure is presented in Figure 1

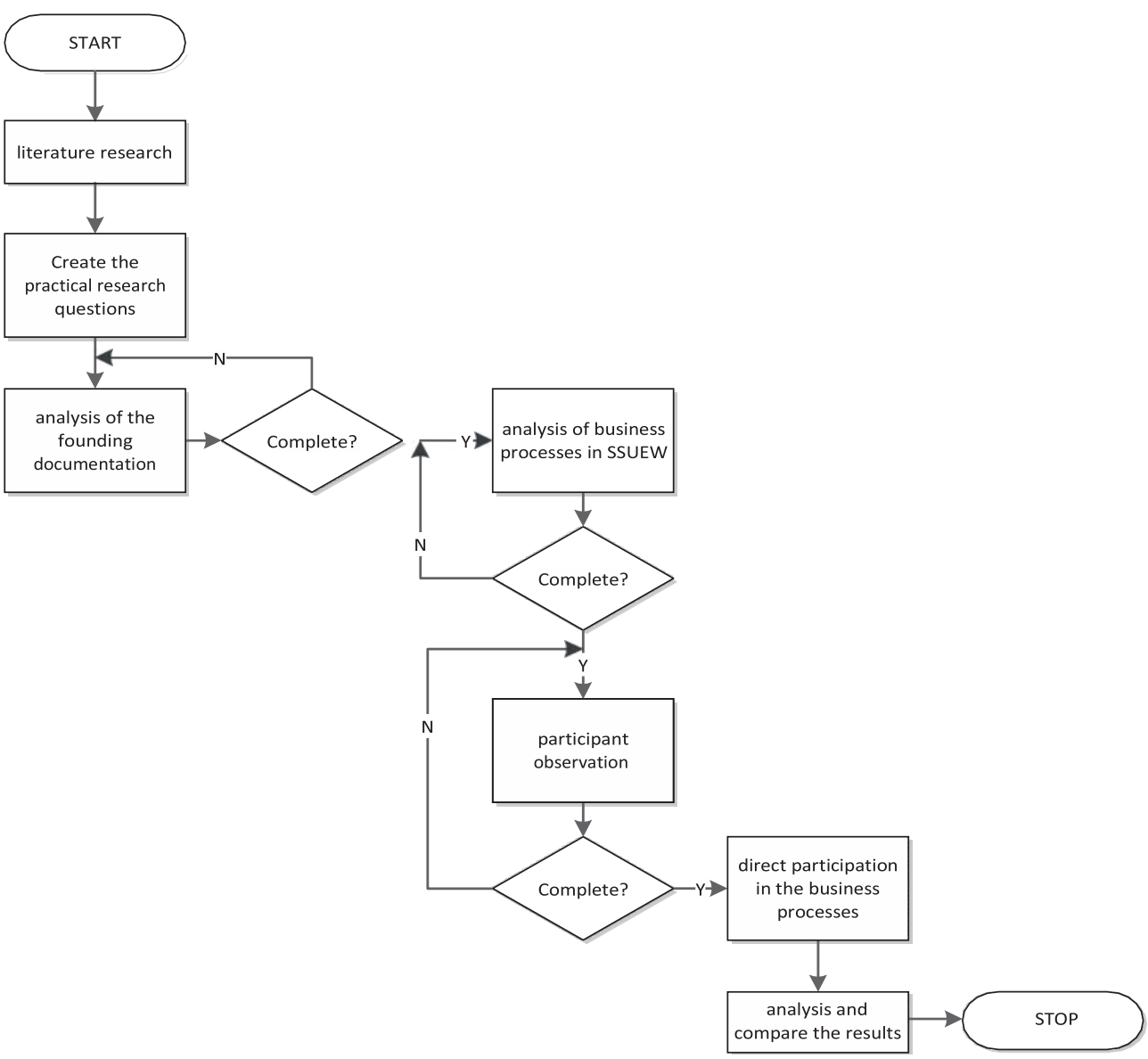

Fig. 1. Procedure of research

Source: own elaboration. 


\section{Results}

Due to the social nature of activities, the information process is one of the key processes in non-profit organizations. Groups of stakeholders who are part of its static structure have a direct impact on the shape and scope of the impact of the information process. Another extremely important element is also the scope of the information resources that they create, acquire or manage. For example, in a non-profit organization such as a Student Government, the following groups of stakeholders can be specified:

1. External stakeholders/recipients:

a) university students;

b) university organizational units;

c) financial partners;

d) boards of student organizations and study groups at the university (ZOiK);

e) self-government bodies, composed of student representatives (the legislative body of the Self-Government - the University Council of the Students' Self-Government and the university resolution-making body - the Senate).

2. Internal stakeholders/recipients: members of the Student Government Committee.

Table 1. presents the most important groups generating information relevant to the nature of the non-profit activities of Student Self-Government.

Table 1. Division of groups generating information relevant to the nature of the activities of the Student Self-Government at the University of Economics in Wrocław

\begin{tabular}{|c|c|c|c|}
\hline $\begin{array}{c}\text { Type } \\
\text { of authority/ } \\
\text { unit }\end{array}$ & $\begin{array}{c}\text { Authority/body } \\
\text { generating } \\
\text { the information }\end{array}$ & $\begin{array}{c}\text { Examples of information to be } \\
\text { generated }\end{array}$ & $\begin{array}{c}\text { Information - gathering } \\
\text { body }\end{array}$ \\
\hline 1 & 2 & 3 & 4 \\
\hline $\begin{array}{l}\text { University } \\
\text { (internal) }\end{array}$ & University Council & $\begin{array}{l}\text { - actions of the rector and } \\
\text { the vice-rectors of the } \\
\text { University; } \\
\text { amendments to the } \\
\text { university statute proposed } \\
\text { by the rector }\end{array}$ & $\begin{array}{l}\text { president of the Student } \\
\text { Self-Government }\end{array}$ \\
\cline { 2 - 5 } & University Senate & $\begin{array}{l}\text { news resulting from } \\
\text { amendments to internal law } \\
\text { voted on by the Senate }\end{array}$ & $\begin{array}{l}\text { Self-Government; } \\
\text { student senators }\end{array}$ \\
\cline { 2 - 5 } & $\begin{array}{l}\text { organisational units } \\
\text { of the University, e.g. } \\
\text { The Dean's Office, The } \\
\text { Promotion Centre }\end{array}$ & $\begin{array}{l}\text { surveys and competitions } \\
\text { for students; } \\
\text { information on the } \\
\text { functioning of a particular } \\
\text { unit, e.g. The Dean's } \\
\text { Office; }\end{array}$ & $\begin{array}{l}\text { member of the Student } \\
\text { Self-Government Board } \\
\text { responsible for the scope } \\
\text { of activities }\end{array}$ \\
\hline
\end{tabular}


Table 1, cont.

\begin{tabular}{|c|c|c|c|}
\hline 1 & 2 & 3 & 4 \\
\hline & & $\begin{array}{l}\text { - information on changes to } \\
\text { legal documents concerning } \\
\text { teaching and student affairs; } \\
\text { - information on changes to } \\
\text { legal documents concerning } \\
\text { teaching and student affairs }\end{array}$ & \\
\hline \multirow[t]{3}{*}{$\begin{array}{l}\text { Other } \\
\text { (external) }\end{array}$} & financial partners & $\begin{array}{l}\text { cooperation reports on } \\
\text { contract concluded and } \\
\text { executed; } \\
\text { advertising posts resulting } \\
\text { from the contracts } \\
\text { concluded }\end{array}$ & $\begin{array}{l}\text { member of the Student } \\
\text { Self-Government Board } \\
\text { responsible for the scope } \\
\text { of activities }\end{array}$ \\
\hline & affiliated bodies* & $\begin{array}{l}\text { - advertising posts resulting } \\
\text { from contracts concluded } \\
\text { by the association; } \\
\text { publicity posts about events } \\
\text { and initiatives jointly } \\
\text { organized by the association }\end{array}$ & $\begin{array}{l}\text { - president of the Student } \\
\text { Self-Government; } \\
\text { - vice-president of } \\
\text { the Student Self- } \\
\text {-Government for } \\
\text { Operations and Public } \\
\text { Relations }\end{array}$ \\
\hline & $\begin{array}{l}\text { social actors and } \\
\text { institutions }\end{array}$ & $\begin{array}{l}\text { - cooperation reports on joint } \\
\text { initiatives; } \\
\text { - posts advertising initiatives }\end{array}$ & $\begin{array}{l}\text { - coordinator of the } \\
\text { initiative; } \\
\text { member of the Student } \\
\text { Self-Government Board } \\
\text { responsible for the } \\
\text { scope of activities }\end{array}$ \\
\hline \multirow[t]{2}{*}{$\begin{array}{l}\text { Local } \\
\text { Government } \\
\text { (internal) }\end{array}$} & $\begin{array}{l}\text { Academic Council of } \\
\text { the Students Self- } \\
\text {-Government (ACSSG) }\end{array}$ & $\begin{array}{l}\text { news on the activities } \\
\text { undertaken by ACSSG; } \\
\text { resolutions and opinions } \\
\text { within the scope of the tasks } \\
\text { of ACSSG }\end{array}$ & $\begin{array}{l}\text { - } \text { president of the Student } \\
\text { Self-Government; } \\
\text { member of the Student } \\
\text { Self-Government Board } \\
\text { responsible for the } \\
\text { scope of activities }\end{array}$ \\
\hline & $\begin{array}{l}\text { Students Self- } \\
\text {-Government Board }\end{array}$ & $\begin{array}{l}\text { news on the activities of } \\
\text { individual board members }\end{array}$ & $\begin{array}{l}\text { - President of the Students } \\
\text { Self-Government; } \\
\text { - Student Self- } \\
\text {-Government Board }\end{array}$ \\
\hline
\end{tabular}

* Affiliated units - associations or agreements in which the Student Government is a member and closely cooperates with other entities belonging to these groups, for example, the Forum of Economic Universities - an agreement between five student self-governments of economic universities in Poland, or, for example, the Students' Parliament of the Republic of Poland, which represents all students and student governments in Poland, and also cooperates with them in various areas.

Source: own elaboration. 
In most of the processes carried out in the Student Self-Government, a special role is played by the Student Self-Government Board, which, together with the President of the Self-Government and the Vice-Presidents, is the main unit collecting the most important information in the field of cooperation with both external and internal bodies/units. Table 1 shows a simplified information flow process in the Student Self-Government.
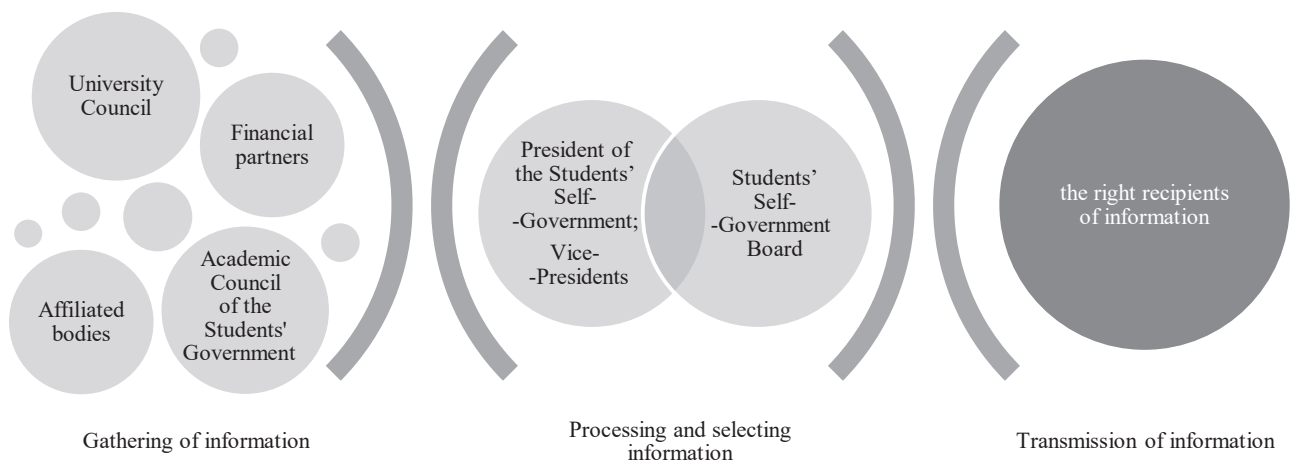

Fig. 2. Diagram of the information flow process in the Student Self-Government

Source: own elaboration.

When presenting the information flow process in the Student Self-Government, an important phenomenon that should be mentioned is the development of this process, which is to ensure reaching a larger group of recipients. In the past, the information flow process focused in particular on students and the internal organs of the Self- Government, such as the Student Self-Government Committees, the Student Council of the Student Self-Government and student organizations operating at the university. The tools used in this process were mainly Facebook (providing information to students) and e-mail groups (internal organs). The information flow process itself was also not so important from the point of view of student representatives, as at that time the focus was more on design activities (created initiatives and projects) than on the transparency of activities and publishing information on a large scale.

Yet, when it comes to typically formal information, in practice e-mail groups and individual e-mails are used. In particular, this type of communication is used in contact with internal recipients (Members of the Committee) as well as external recipients, which are self-government bodies, such as the legislative body - the University Council of the Student Self-Government. The nature of messages generated to these groups via e-mails indicates the higher level of their formality and importance. 


\section{Discussion}

The analysis of the actual state of affairs concerning the subjective scope of the processes occurring in the Student Self-Government allows to draw conclusions re- garding the essence of their occurrence, as well as the changes taking place over time resulting from the generational and technological aspects. The formalization of stakeholder groups and information resources that are interesting to them, and necessary for the proper conduct of business, increases the transparency of the Student Government's activities. The formalization and digitalization of information resources transferred between stakeholder groups in non-profit organizations contributes to an increasingly better functioning of information processes.

For example, in the era of ever-increasing digitalization, communication channels such as Facebook or a website are much better suited to contact with students than e-mails. This is mainly due to the fact that students, as young people, spend much more time on portals adapted to communication on a regular basis, where they can not only communicate with their friends, but also follow well-known companies or other entities' information drawn from private life or their daily activities. In this case, where the scale of recipients is also very large (currently there are over 10,000 students at the Wroclaw University of Economics in Business), sending e-mails on various topics would not only be met with very little interest, but in particular with a lack of real opportunities to communicate with student representatives generating messages and communicating them to students. Such solutions provide, above all, the possibility of ongoing contact with the student in the form of communication via a chat on the fanpage, functioning on Facebook or Instagram, and thus it is more certain that the information will reach a specific group of recipients and reciprocal contact/reaction will take place.

Increasing use of social media by young people, including students, over the last five years has also resulted in the need to adapt the tools used to improve communication with external recipients, i.e. stakeholders of the organization. This relationship was also influenced by the approach of the persons responsible for supervising these tools and updating information on them. Changing the approach and the willingness to introduce new solutions to communication with content recipients over the course of five years, has resulted in the increasing use of modern tools for creating, collecting and transferring information resources between individual stakeholders of a non-profit organization, such as the Student Self-Government.

\section{Conclusion}

The article identifies and presents groups of stakeholders who create and cooperate closely with the Students' Self-Government as an example of a non-profit organization.

Specified groups of stakeholders are interested in access to other information resources, which means that each of the mentioned groups is waiting for the delivery 
of different information resources. Therefore, such an extremely important element in the process of improving business processes is to define the main groups of stake- holders and information resources that are expected and processed by them. In terms of the analysed stakeholder groups, an important conclusion is not only the necessity to adjust communication tools to the characteristics of the individual groups, but also to pay attention to the effective planning of the process of obtaining, processing and transmitting information. The choice of communication tools alone may not be effective enough due to the mismatch between the processes in the business processes and the specific stakeholder group. Importantly, when creating or improving communication processes, it is necessary to update the effectiveness of the tools absorbed in these processes. This necessity arises in particular from the dynamics of stakeholder groups, whose members are young people, who increasingly use new technologies and new communication solutions.

However, the assumption regarding the age of group members should not be an overriding assumption, as the determinant of a change in the communication process may also be a change in the characteristics of a given stakeholder group, such as the shift from stationary to remote operation related to the coronavirus pandemic. In such a case, the tools themselves, although well chosen, may not meet the required business and communication process objectives. Another important element in such a situation will be the analysis of technological possibilities and the selection of new or additional communication tools, as well as the updating or replacement of ineffective ones.

The findings of the article result from the authors' experience in the field of student activity and the practical application of the previously indicated communication tools, as well as participation in the information flow process, both from the perspective of the sender and the recipient of specific information.

\section{References}

Bode, I. (2006). Disorganized welfare mixes: Voluntary agencies and new governance regimes in Western Europe. Journal of European Social Policy, 16, 346-359.

Dart, R. (2004). Being 'business-like' in a non-profit organization: A grounded and inductive typology. Non-Profit and Voluntary Sector Quarterly, 33, 290-310.

Domański, J. (2010). Zarządzanie strategiczne organizacjami non profit w Polsce. Warszawa: Wydawnictwo Wolters Kluwer Polska Sp. z o.o.

Fudaliński, J. (2013). Perspektywy rozwoju zarzadzania społecznego w sektorze organizacji non profit w Polsce. Warszawa: Wydawnictwo Difin.

Gliński, P. (2006). Style działań organizacji pozarządowych w Polsce. Grupy interesu czy pożytku publicznego? Warszawa: Wydawnictwo IFiS PAN.

Grzelońska, U. (2011). Rola sektora non-profit w polskiej gospodarce. Studia Ekonomiczne, 4(71), 325-344.

GUS. (2019). Zeszyt metodologiczny: Organizacje non-profit: stowarzyszenia, fundacje, samorzad gospodarczy i zawodowy oraz społeczne jednostki wyznaniowe. Kraków, Warszawa: Departament Badań Społecznych. 
Handbook on non-profit institutions in the system of national accounts. (2003). New York: United Nations. Retrieved April 24, 2019 from https://unstats.un.org/unsd/publication/seriesf/seriesf_91e.pdf

Hwang, H., and Powell, W. W. (2009). The rationalization of charity: The influences of professionalism in the non-profit sector. Administrative Science Quarterly, 54, 268-298.

Kreutzer, K., and Jäger, U. (2011). Volunteering versus managerialism: Conflict over organizational identity in voluntary associations. Non-Profit and Voluntary Sector Quarterly, 40, 634-661.

Mrzygłocka-Chojnacka, J. (2014). Rola i czynniki zaufania $w$ działalności organizacji zorientowanych społecznie. Warszawa: Wydawnictwo IPSiIR UW.

Praska-Kruszyńska, J. (2003). Realizacja zadań państwa poprzez organizacje „,nonprofit”. In D. Kopycińska (red.), Państwo i rynek w gospodarce (p. 82). Szczecin.

Shaw, S., and Allen, J. B. (2009). "To be a business and to keep our humanity": A critical management studies analysis of the relationship between a funder and non-profit community organizations. Non-Profit Management \& Leadership, 20, 83-96.

Szulc, J. (2010). Zarządzanie finansami w instytucji non-profit. Problemy i wyzwania. Biuletyn Bibliotek Kościelnych, 1-2(30-31), 81-99.

Ustawa z dnia 24 kwietnia 2003 r. o działalności pożytku publicznego i o wolontariacie (tekst jedn.: Dz. U. z 2018 r., poz. 450 z późn. zm.)

Zawadzki, J. (2007). Zarzadzanie organizacjami non-profit. Zagadnienia wybrane. Poznań: Wydawnictwo Forum Naukowe. 